\title{
Maternal Sensitivity, Mother-Child Attachment, and Cognitive Development of Preschool Children In Urban Poor Areas
}

\author{
Elien Surya Hadhyastuti* \\ Department of Family and Consumer Sciences, \\ Faculty of Human Ecology, \\ Bogor Agricultural University \\ Department of Family and Consumer Sciences, \\ Faculty of Human Ecology, \\ Bogor Agricultural University \\ *Corresponding author: elien.hadhyastuti@gmail.com
}

\begin{abstract}
This research aimed to analyze the influence of maternal sensitivity on mother-child attachment, and mother-child attachment on cognitive development. This research was conducted at Kelurahan Empang and Tegallega, Kota Bogor. The samples consist of 100 mothers and their child that were selected by proportional random sampling. The results showed that mother's education length and maternal sensitivity has positive significant correlation with mother-child attachment. In addition, mother's education length and income per capita has positive significant correlation with cognitive development. However, family size has negative significant correlation with motherchild attachment and also cognitive development. Child cognitive development was influenced by participation in early childhood education and mother's education length. This research found that child cognitive development was not influenced by motherchild attachment.
\end{abstract}

Keywords: attachment, cognitive development, early childhood education, maternal sensitivity, poverty

\begin{abstract}
Abstrak
Penelitian ini bertujuan untuk menganalisis pengaruh sensitivitas ibu, kelekatan ibuanak, dan perkembangan kognitif anak usia prasekolah di wilayah miskin perkotaan. Penelitian ini dilakukan di Kelurahan Empang dan Tegallega, Kota Bogor yang melibatkan 100 contoh anak yang berusia 3-6 tahun beserta ibu yang dipilih secara proportional random sampling. Hasil penelitian menunjukkan bahwa lama pendidikan ibu dan sensitivitas ibu berhubungan positif signifikan dengan kelekatan ibu-anak. Lama pendidikan ibu dan pendapatan per kapita berhubungan positif signifikan dengan perkembangan kognitif anak. Besar keluarga berhubungan negatif signifikan dengan kelekatan ibu-anak dan perkembangan kognitif. Keikutsertaan ECEP dan lama pendidikan ibu berpengaruh positif terhadap perkembangan kognitif anak. Penelitian ini menunjukkan tidak adanya pengaruh yang signifikan antara kelekatan ibu-anak dengan perkembangan kognitif anak.
\end{abstract}

Kata kunci: kelekatan ibu-anak, kemiskinan, ECEP, perkembangan kognitif, sensitivitas ibu 


\section{Introduction}

Indonesia is a developing country with a population of 252164.8 thousand people (BPS 2015) and has several problems such as high growth rate and poverty. According to BPS data, the number of poor people in Indonesia in March 2015 is as much as 28.59 million people or about 11.22 percent. West Java province is in the third position of the largest number of poor people in Indonesia with the number of poor people as much as 4238.96 thousand people in September 2014. Bogor city has a poor population of 8.19 percent in 2013 (BPS 2015).

Poor families tend to have some problems, one of which is the development of children who are late. Marlina's (2012) research results in poor families said that more than half of children have less cognitive development. Briawan and Herawati (2008) stated that poor families have slow development, and low stimulation. Though the family is the first place for children to learn and interact. Interaction in the family can be through the parenting process. Maternal parenting that is sensitive to the needs of the child will form a secure mother-child attachment. The results of Mills-Koonce et al. (2007) states that there is a relationship between maternal sensitivity and mother-child attachment. Maternal care that is sensitive to the needs of the child will form a secure attachment between mother and child (Kunster et al.2010). In addition, sensitive mother-care can predict children's cognitive abilities. Mills-Koonce et al. (2015) states that there is a relationship between sensitive parental care with the cognitive abilities of children.

Maternal-child attachment can also affect children's cognitive development. Hastuti (2015) states that the bonds that exist between mother and child are vehicles to develop their physical, emotional, and intellectual aspects. Children who have a secure attachment to the mother will have good cognitive development (Craig 1993; Pierrehumbert et al. 1996; Spieker et al. 2003). Insecure and avoidant attachment is a negative predictor of the cognitive abilities of children (O'Connor and McCartney 2007).

The cognitive development of preschool children occurs quickly because at this age the child is in the golden age. At this time it is important for children to get stimulation in order to have optimal development. Giving stimulation can be given at home and at school. However, the poor tend to be more concerned with meeting their food needs first. The results of Hastuti et al. (2010) states that poor families are more concerned with meeting food needs first. So that children do not get the game tools to stimulate children to have good cognitive development. The results of this study indicate that long attend the Early Childhood Education Program (ECEP) can affect the cognitive development of children (Hastuti et al. 2010). However, there are still many children who have not received educational services. This can be seen from the participation of children who attend ECEP. The participation rate of ECEP in Bogor City is 51.87 percent for 2014/2015 (Kemendikbud 2015). This indicates that there are still many children who have not received education services. In the case of children attending ECEP, children will get stimulations that will improve their development as well assisting school children's readiness.

Based on those explanations, this study aims to: (1) Analyze differences in child characteristics, family characteristics, maternal sensitivity, mother-child attachment, and cognitive development in preschool-aged children who attend ECEP and who do not attend ECEP; (2) Analyze the relationship between child characteristics, family 
characteristics, maternal sensitivity, mother-child attachment and cognitive development; (3) Analyze the influence between child characteristics, family characteristics, maternal sensitivity, and mother-child attachment to cognitive development.

\section{Methods}

Design of this research is a cross sectional study, a research conducted at one time. The location of the research was conducted in Kelurahan Empang, Kecamatan Bogor Selatan and Kelurahan Tegallega, Kecamatan Bogor Tengah. The selection of research sites was done purposively, because the two locations were the most PreProsperous Family (PPF) and Prosperous Family I (PF I) in Bogor City according to BPS (2015) data. This study was conducted from February to June 2016. The population in this study were preschool and mothers who belonged to PPF and PF I groups in Kelurahan Tegallega, Kecamatan Bogor Tengah and Kelurahan Empang, Kecamatan Bogor Selatan. Examples in this study are children aged 3-6 years and mother as a primary caregiver. Sampling is used a proportional random sampling. The total number of selected samples is 100 children, 50 children attending ECEP consist of 38 children in Kelurahan Tegallega and 12 children in Kelurahan Empang, and 50 children who do not attend ECEP consisting of 33 children in Kelurahan Tegallega and 17 children in Kelurahan Empang .

Primary data was obtained through interview and observation using questionnaire. Primary data include sample characteristics, family characteristics, maternal sensitivity, mother-child attachment, and cognitive development. Maternal sensitivity was measured using a questionnaire adopted from a Sukardi (2011) study consisting of five dimensions (facial expression, speech expression, position and physical contact, affectionate expression, and discipline control), and consisted of 25 questions and had Cronbach's alpha of 0.773 with 4 scales ie $1=$ never, $2=$ rare, $3=$ sometimes, 4 = frequent. The mother-child attachments were measured using the Q-Sort Questionnaire Attachment questionnaire developed by LaMont (2010) and modified by Dewanggi et al. (2015), consists of 12 questions and has Cronbach's alpha of 0.702 and uses 3 scales ( $1=$ unmatched, $2=$ sometimes appropriate, $3=$ appropriate). The child's cognitive development was measured using a Depdiknas instrument consisting of 13 grain statements and having Cronbach's alpha of 0.907. Maternal sensitivity, motherchild attachment, and cognitive development of children are categorized based on index scores achieved and incorporated into three categories, such as low (score <60), moderate (score 60-80), and height (score>80). Data analysis was done descriptively and inferensia. Descriptive analysis is used to know the value of maximum and minimum, mean value and standard deviation. Inference analyzes used included independent sample t-test, correlation test, and linear regression test.

\section{Result}

\section{Characteristics of Child and Family}

The results showed that half of the children $(50 \%)$ had attended the ECEP program. As many as 60 percent of children are female and the rest (40\%) are male. More than half of the children (67\%) have an age range of 5-6 years. Most children $(90 \%)$ who attend ECEP are in the age range of 5-6 years and the rest (10\%) are in the 
4-5 year age range. In children who did not attend as many as 44 percent were in the range of 4-5 years and ranges of 5-6 tahun.Hasil research indicates that as many as 40 percent of children who attend ECEP is the eldest, the rest is the middle child (22\%) and youngest child (38\%) In children who do not attend ECEP as much as 46 percent of children are the youngest, and as many as 30 percent are middle children.

More than half of the children who attended ECEP (52\%) had middle-aged fathers and 82 percent of children had younger adult mothers. In children not attending ECEP more than half of the children $(58 \%)$ had younger adult fathers and as many as $88 \%$ children had young adult mothers. The results showed that there was a significant difference between the families of children attending the ECEP and children who did not attend the ECEP $(\alpha<0.05)$. The average family size of children who do not attend the ECEP (5.10) is larger than children attending ECEP (4.52). The length of father education in children attending ECEP is significantly different with children who do not attend ECEP $(\alpha<0.01)$. The average length of education of fathers of children attending ECEP (9.16) is greater than the length of education of fathers of children not attending ECEP (7.48). The length of education of mothers in children attending ECEP is significantly different with children who do not attend ECEP $(\alpha<0.01)$. The average length of education of mothers of children who attend ECEP (8.52) is greater than the length of education of mothers of children who do not attend the ECEP (6.66). There is no significant difference between father's age, maternal age, and income per capita in children who attend ECEP with which does not attend ECEP $(\alpha>0.05)$. Children who attended ECEP have an average age of 38.76 years of father, while in children who do not attend the ECEP is 38.66 years. Maternal age in children who attend the ECEP has an average of 33.76 years, while the age of mothers in children who do not attend the ECEP has an average of 32.96 years. Families in the group of children attending ECEP had an average per capita income of IDR 463560 , whereas in the group of children who did not attend the ECEP, the average per capita income was IDR 393 300. The results showed that 51 percent of children were in the non-poor category because it has per capita income above the Bogor poverty line, which is IDR 360 518, and the rest (49\%) are in the poor category. This indicates that in urban poor study sites there are 51 percent of non-poor families according to the Bogor BPS poverty line 2015.

\section{Maternal Sensitivity}

The results of the study in Table 1 showed that the sensitivity of mothers was in the middle category, both in children who attend ECEP (66\%) and those who did not attend ECEP (58\%). In facial expression dimension, both children who attended ECEP $(78 \%)$ and those who did not attend ECEP (72\%) were in the moderate category. Similarly, the dimension of speech expression, where children who attend ECEP (74\%) and who do not attend the ECEP (54\%) are in the medium category. In the position and physical contact dimension of children attending ECEP is in the high category (52\%), whereas children who do not attend ECEP are in moderate category $(46 \%)$. In the dimension of expression of affection both children who attend the ECEP (46\%) and those who do not attend the ECEP $(58 \%)$ are in the same category, namely the moderate category. Dimension of disciplinary control is in the low category good for children who attend ECEP $(60 \%)$ or those who do not attend the ECEP (72\%). Low disciplinary control is seen from more than half of mothers often scolding children when disobedient, mothers sometimes prohibit children physically, and only 19 percent of 
mothers often direct children to eat on time and only 15 percent of mothers who often supervise their children while playing.

The results showed that the sensitivity of mothers in children who attend the early childhood and who do not attend the early childhood is not significantly different $(\alpha>0.05)$. Similarly, facial expressions, speech expression, physical position and contact, affectionate expression, and discipline control of children attending the early childhood do not have significant differences with children who do not attend the early childhood. However, the mean sensitivity of mothers of children attending Early Childhood Education Programs (ECEP) (69.2) was higher than those who did not attend ECEP (66.9). This shows that children who attend ECEP have a more sensitive mother than mothers who have children who do not attend the ECEP. When viewed from all children, position and physical contact dimensions (79.8), as well as facial expression dimensions (73.2) have the highest average score, and discipline control dimensions (51.2) have the lowest average scores.

Table 1 Distribution of children based on maternal sensitivity in children who attend and who not attend ECEP

\begin{tabular}{|c|c|c|c|c|c|c|c|c|c|}
\hline \multirow[t]{3}{*}{ Variable } & \multicolumn{3}{|c|}{ Follow ECEP } & \multicolumn{3}{|c|}{ Not Follow ECEP } & \multicolumn{3}{|c|}{ Total } \\
\hline & Low & Medium & High & Low & Medium & High & Low & Medium & High \\
\hline & $\%$ & $\%$ & $\%$ & $\%$ & $\%$ & $\%$ & $\%$ & $\%$ & $\%$ \\
\hline Facial expression & 8 & 78 & 14 & 10 & 72 & 18 & 9 & 75 & 16 \\
\hline Speech expression & 12 & 74 & 14 & 30 & 54 & 16 & 21 & 64 & 15 \\
\hline $\begin{array}{l}\text { Position and } \\
\text { physical contact }\end{array}$ & 6 & 42 & 52 & 14 & 46 & 40 & 10 & 44 & 46 \\
\hline $\begin{array}{l}\text { Expression of } \\
\text { affection }\end{array}$ & 28 & 46 & 26 & 22 & 58 & 20 & 25 & 52 & 23 \\
\hline $\begin{array}{l}\text { Disciplinary } \\
\text { control }\end{array}$ & 60 & 40 & 0 & 72 & 24 & 4 & 66 & 32 & 2 \\
\hline Maternal sensitivity & 18 & 66 & 16 & 26 & 58 & 16 & 22 & 62 & 16 \\
\hline
\end{tabular}

\section{Mother-Child Attachment}

The results of the study in Table 2 show that as many as 59 percent of all children have low-birth attachment of mothers and children. In children who attend the ECEP as much as 58 percent are in the low category. As many as 60 percent of children who do not attend ECEP are in the low category. Only 4 percent of children who have high attachment with mothers of both children who attend the early childhood and who do not attend the ECEP.

Table 2 Distribution of children based on mother-child attachment in children who follow and who not follow ECEP

\begin{tabular}{lcccccc}
\hline Category of & \multicolumn{2}{c}{ ECEP } & \multicolumn{2}{c}{ Non-ECEP } & \multicolumn{2}{c}{ Total } \\
\cline { 2 - 8 } attachment & $\mathrm{n}$ & $\%$ & $\mathrm{n}$ & $\%$ & $\mathrm{n}$ & $\%$ \\
\hline Low & 29 & 58 & 30 & 60 & 59 & 59 \\
Medium & 19 & 38 & 18 & 36 & 37 & 37 \\
High & 2 & 4 & 2 & 4 & 4 & 4 \\
\hline Total & 50 & 100 & 50 & 100 & 100 & 100 \\
\hline Min-max & & $29.1-87.5$ & \multicolumn{2}{c}{$16.7-87.5$} & $56.7-87.5$ \\
Mean \pm Dev. Std & $58.0 \pm 13.2$ & \multicolumn{2}{c}{0.477} & \\
-value & & \multicolumn{3}{c}{} \\
\hline
\end{tabular}


The low maternal-child attachment seen from as many as 50 percent of children in this study did not follow and resume the game when the mother migrated, as many as 45 percent of the children did not look for mothers, when the children played around the house, and only 30 percent of the children were able to calm down someone other than the mother when the child is angry or hurt. Different test results indicate that the attachment of mother-children attending ECEP was not significantly different from those not attending ECEP $(\alpha>0.05)$. However, the mean attachment of mother-children attending ECEP (58.0) was higher than those who did not attend ECEP (55.9). This shows that children who attend ECEP closer to the mother than children who do not attend the ECEP.

\section{Cognitive Development}

The results of the study in Table 3 show that as many as 42 percent of all children have cognitive development in the moderate category. As many as 48 percent of children who attend ECEP have cognitive development in the moderate category. This is seen from more than half of children attending ECEP have been able to recognize 6-10 letters, recognize the currency, grouping objects by shape and color, completing the puzzle to completion. However, the child has not been able to name the complete home address, mention the age and date of birth correctly, and mention the names of the months in a year completely and in sequence.

Children who do not attend ECEP have cognitive development in the low category (56\%). Almost half of children who do not attend the ECEP are able to name and distinguish the larger one between goats and mice, matching colors, pairing images of known objects, recognizing currency, grouping objects by color or shape, and already able to mimic cube patterns. However, the child still has not been able to name 5-9 colors or more, mention the age and date of birth correctly, mention 1-45, mention the names of days and months in a year completely and consecutively, identify 6-10 letters, and mention complete home address.

Table 3 Distribution of children based on cognitive development in children who attend and who not attend ECEP

\begin{tabular}{lcccccc}
\hline Cognitive & \multicolumn{2}{c}{ ECEP } & \multicolumn{2}{c}{ Non-ECEP } & \multicolumn{2}{c}{ Total } \\
\cline { 2 - 7 } Development & $\mathrm{n}$ & $\%$ & $\mathrm{n}$ & $\%$ & $\mathrm{n}$ & $\%$ \\
\hline Low & 10 & 20 & 28 & 56 & 38 & 38 \\
Medium & 24 & 48 & 18 & 36 & 42 & 42 \\
High & 16 & 32 & 4 & 8 & 20 & 20 \\
\hline Total & 50 & 100 & 50 & 100 & 100 & 100 \\
\hline Min-max & $42.3-97.4$ & \multicolumn{2}{c}{$26.9-89.7$} & $26.9-97.4$ \\
Mean \pm Dev. Std & $71.6 \pm 12.8$ & \multicolumn{2}{c}{$56.5 \pm 15.3$} & $64.0 \pm 15.9$ \\
$p$-value & & $0.000^{* *}$ & \\
\hline
\end{tabular}

Description: $*=$ significant at $\mathrm{p}$-value $<0.05 ; * *=$ significant at $\mathrm{p}$-value $<0.01$

The results showed that cognitive development of children attending ECEP was significantly different with those who did not attend ECEP $(\alpha<0.01)$. The mean of cognitive development of children attending ECEP (71.6) was higher than those who did not attend ECEP (56.5). shows that cognitive development of children who attend the ECEP better than children who do not attend the ECEP. 


\section{Relationship of Family Characteristics, Child Characteristics, Maternal Sensitivity, Mother-Child Approach, and Child Cognitive Development}

The result of correlation test in Table 4 shows that there is a significant positive correlation between maternal education length and mother-child attachment $(r=0.216$; $\mathrm{p}<0.05)$. This means that the longer the mother takes education the better the attachment between mother and child. Maternal sensitivity has a significant positive relationship with mother-child attachment $(r=0.479 ; \mathrm{p}<0.01)$. That is, the better the mother's sensitivity, the better the attachment between mother and child. The results of the correlation test also showed that there was a significant negative relationship between family size and mother-child attachment $(r=-0.242 ; p<0.05)$. This means that the more the number of family members the mother-child attachment will get worse. There was a very significant positive relationship between maternal education length and cognitive development of children $(r=0.382 ; \mathrm{p}<0.01)$. That is, the longer the mother takes education the better the child's cognitive development. Per capita income also has a significant positive relationship with cognitive development of children $(\mathrm{r}=$ $0.202 ; \mathrm{p}<0.05)$. This means that the greater the per capita income, the better the child's cognitive development. Large families had significant negative associations with cognitive development of children $(r=-0.233 ; \mathrm{p}<0.05)$. This means that the greater the number of family members the worse the child's cognitive development.

Table 4 Coefficient of correlation of family characteristics, child characteristics, maternal sensitivity, mother-child attachment, and cognitive development

\begin{tabular}{lccc}
\hline Variable & $\begin{array}{c}\text { Maternal } \\
\text { sensitivity }\end{array}$ & Attachment Mother-Child & Child's Cognitive \\
\hline Child Age (years) & -0.160 & -0.149 & 0.183 \\
Mother's age (years) & 0.084 & -0.018 & -0.004 \\
Length of mother's education & 0.119 & $0.216^{*}$ & $0.382^{* *}$ \\
(years) & & & \\
Family size (persons) & -0.182 & $-0.242^{*}$ & $-0.233^{*}$ \\
Income per capita (IDR / month) & 0.027 & 0.120 & $0.202^{*}$ \\
Maternal sensitivity & 1.000 & $0.479^{* *}$ & 0.127 \\
Attachment Mother-Child & $0.479^{* *}$ & 1.000 & 0.153 \\
\hline
\end{tabular}

Description: $*=$ significant at $\mathrm{p}$-value $<0.05 ; * *=$ significant at $\mathrm{p}$-value $<0.01$

\section{Influence of Family Characteristics, Child Characteristics, Mother Sensitivity and Mother-Child Attachment to Child's Cognitive Development}

The model of variables that influence the child's cognitive development compiled in this study has an Adjusted R-square value of 0.250. The Adjusted R-square value indicates that the model only explains the 25.0 percent influence of the variables studied on the cognitive development variable of the child, while the rest of 75.0 percent is influenced by other variables not studied. The results of the influence test in Table 12 show that the participation of ECEP $(\beta=12.158)$ has a significant positive effect on the cognitive development of children. This means that each increment of one unit of ECD participation will increase the child's cognitive development by 12,158 points. The duration of maternal education has a significant positive effect on the child's cognitive development $(\beta=1.118)$. This means that every increase of one maternal education unit will increase child cognitive development by 1,118 points. 
Table 5 Regressioncoefficients of factors that affect cognitive development of children

\begin{tabular}{lrrr}
\hline Variable & \multicolumn{3}{c}{ Child's cognitive development } \\
\cline { 2 - 4 } & $\begin{array}{c}\text { Unstandardized } \\
\beta\end{array}$ & $\begin{array}{c}\text { Standardized } \\
\beta\end{array}$ & \multicolumn{1}{c}{ Sig } \\
\hline Constant & 43.830 & & 0.001 \\
ECEP participation (0 = no early childhood, & 12.158 & 0.382 & $0.000^{* *}$ \\
1 = early childhood) & & & \\
Mother's age (years) & 0.087 & 0.033 & 0.753 \\
Length of mother's education (years) & 1.118 & 0.219 & $0.028^{*}$ \\
Family size (persons) & -0.765 & -0.070 & 0.540 \\
Income per capita (IDR / month) & $3.379 \mathrm{E}-6$ & 0.057 & 0.555 \\
Maternal sensitivity & 0.033 & 0.022 & 0.826 \\
Attachment Mother-Child & 0.049 & 0.044 & 0.664 \\
\hline $\mathrm{R}^{2}$ & & 0.303 & \\
$\mathrm{R}^{2}$ Adjusted & & 0.250 & \\
$\mathrm{~F}$ & & 5.715 & \\
Sig. & & 0.000 & \\
\hline
\end{tabular}

Keterangan: *=signifikan pada p-value $<0.05 ; * *=$ signifikan pada p-value $<0.01$

\section{Discussion}

Maternal sensitivity is the ability of the mother to capture the signals and the mother's response to meet the needs of the child. The results showed that the sensitivity of the mother included in the medium category. This is in line with the results of research conducted by Sukardi (2011) that mom sometimes shows her positive emotions through smiling expression, speaks softly, looks at face while talking, gives a touch like hugging or stroking, but on the other hand also shows negative emotions by scolding children when not in a high tone, rarely say the word dear, and prohibit children physically.

Maternal sensitivity is positively significant with mother-child attachment. This means that the better the mother's sensitivity, the better the mother-child attachment. The results of Gartstein and Iverson's (2014) study suggest that more sensitive mothers in their interactions with children facilitate safe attachment development with their children. This is because maternal sensitivity shows proper understanding and interpretation and provides prompt and precise response to both verbal and nonverbal expressions Grossmann and Grossmann 2009). Increased sensitivity of the parents will improve safe attachment (Kranenburg et al., 2003). Sensitive or insensitive parenting parenting has a key role in the emergence of secure or insecure attachment (Ijzendoorn 2007).

Bowlby's attachment theory emphasizes the importance of attachment in the early years of life and the importance of caregiver responsiveness (Santrock 2007b). Mother-child attachment in this study was in the low category. According to Megawangi (2014), mothers living in poverty (especially urban slums) tend to be difficult to establish safe attachment to children. This is because mothers have higher levels of stress due to generally lower economic, knowledge and educational problems. The results of research conducted by Dewanggi et al. (2015) suggests that the motherchild attachment living in urban areas is lower than the mother-child attachment in rural areas. This is because secure attachment is built better in rural areas and mothers are 
always in the village so close to the child and can respond quickly to the child's condition. Mothers who are more responsive in children have a higher level of attachment (Rispoli et al. 2013).

The results of this study indicate that the duration of maternal education is positively significant with mother-child attachment. This means that the higher the length of the mother's education the better the mother-child attachment. Mothers with high socioeconomic status tend to recognize and respond to children appropriately (Falco et al 2014). Large families are significantly negative in relation to mother-child attachment, which means that the greater the number of family members the worse the mother-child attachment. The results of Saputri (2010) show that large families will affect the attention given to parents of children.

The child's cognitive development is in the moderate category. The results of this study are in accordance with research conducted by Warsito et al. (2012) suggesting that the cognitive development of preschoolers is in the moderate category. Children who follow the ECEP have better cognitive development than children who do not attend the ECEP. This is because children who attend ECEP have more academic benefits (Loeb et al. 2007). The results of research Hastuti et al. (2010) states that the duration of ECEP education has a significant positive effect on children's cognitive development.

The cognitive development of children aged three to six years according to Piaget is at the preoperational stage. At this stage children begin to represent their world with symbols such as words, shadows, and images. At this time the child develops views that are still simple, and not very good to think of things further (Santrock 2007a). In this study, children who attend the early childhood in general are able to recognize the symbols and grouping objects in accordance with its characteristics. However, children who do not attend ECEP almost half the children are able to group objects in accordance with its characteristics and have not been able to recognize the symbol.

Maternal education and per capita income are positively associated with children's cognitive development. This means that the higher the length of maternal education, and the greater the per capita income, the better the child's cognitive development. The results of Warsito et al. (2012) states that maternal education and per capita income are positively associated with cognitive development of children. Children from non-poor families have better cognitive (Hanum and Khomsan 2012). The results of Setyaningrum et al. (2014) stated that children with low cognitive scores were more likely to be mothers with low education, low knowledge, and younger age. Large families are significantly negatively associated with cognitive development of children. The results of Hanum and Khomsan (2012) suggest that children who come from small families have better cognitive development. This is because the large family creates a favorable atmosphere and the mother is more focused in stimulating the child.

The participation of ECEP and maternal education has a positive effect on children's cognitive development. This is in accordance with the results of previous research which states that the duration of maternal education has a positive effect on cognitive development of children (Hastuti et al. 2010), and the participation of early childhood is one of the factors that can improve the cognitive development of children (Warsito et al. Meanwhile Malmberg et al. (2010) suggest that stimulation in schools has a beneficial effect on cognitive development of children. 
There was no significant effect between maternal sensitivity and mother-child attachment to cognitive development of children. In this study, the achievement of mother's sensitivity and mother-child attachment in ECEP and non-ECEP groups tend to be the same. It is suspected to cause no significant effect between maternal sensitivity and mother-child attachment to cognitive development of children. However, maternal sensitivity is one of the factors that can shape mother-child attachment (Ponciano 2010). This can be seen from the test results of the relationship between the mother's sensitivity with mother-child attachment. In addition, based on interview results, some mothers engage fathers and other family members (grandparents) in daily parenting. This allows the child to be more attached to other figures than the mother. Elderly participation is more influential on children's cognitive development than mother-child attachment. This can be seen from the average score of cognitive development of children who attend the ECEP higher than children who do not attend the early childhood. The results of this study are in line with Aini research (2015) which shows no relationship between attachment to cognitive development of children. However, the results of this study do not coincide with the results of previous studies in which children with good attachment will have good cognitive development (West et al., 2012).

\section{Conclusion and Suggestion}

\section{Conclusion}

The results show that more than half of the parents in this study were at a young adult age with a large average family of 4-5 people. Education taken by father and mother on average is at junior level. Average per capita income is IDR 428420 . More than half of children aged 5-6 years. Maternal sensitivity is in the moderate category, whereas mother-child attachment is in the low category. There was no significant difference between maternal sensitivity and mother-child attachment attending ECD and non ECEP. However, the average child who attended ECEP has better maternal and maternal-to-child attachment. The child's cognitive development is in the moderate category. There is a significant difference between children attending ECEP and those who are not ECEP, where the average of children who attend ECEP is higher than those who do not attend ECEP. The result of relationship test shows that the longer the mother's education and the better the mother's sensitivity, the better the mother-child attachment. However, the more the number of family members the worse the motherchild attachment. Meanwhile, the longer the mother's education and the greater the income per capita, the better the cognitive development of the child. The more the number of family members the child's cognitive development gets worse. The participation of ECEP and maternal education has a positive influence on children's cognitive development.

\section{Suggestion}

Maternal-child attachment is also still relatively low so it is important for parents to more often do quality interactions with children and more sensitive to the needs of children. Children who attend ECEP have better cognitive development so it is important for parents to include children in the ECD program. However, for parents who are unable to include children in an ECEP program it is important to provide stimulation at home in order for the child to achieve good cognitive development. In 
addition, it is important for the government to provide ECEP with good facilities for children who are not economically able to get children stimulated from school. Subsequent research is suggested for further research to see and analyze other factors such as maternal psychosocial stimulation, teacher-child attachment, or school environment quality.

Aini, S. (2015). Kualitas lingkungan pengasuhan, kelekatan ibu-anak, dan perkembangan kognitif anak usia prasekolah pada keluarga dengan ibu bekerja [skripsi]. Bogor (ID): Institut Pertanian Bogor

[BPS] Badan Pusat Statistik. (2015). Bogor dalam angka 2015. Jawa Barat dalam angka 2015. Statistik Indonesia 2015.

Briawan, D., Herawati, T. (2008). Peran stimulasi orang tua terhadap perkembangan anak balita keluarga miskin. Jur. Ilm. Kel. \& Kons. 1 (1) 63-76

Craig, C.Mc.C. (1993). The relation between cognitive development and attachment in 3 years old [disertasi]. California (US): Wright Institute.

Dewanggi, M., Hastuti, D., Herawati, T. (2015). The influence of attachment and quality of parenting and parenting environment on children's character in rural and urban areas of Bogor. Jur. Ilm. Kel. \& Kons. 8 (1) 20-27

Falco, S.D., Emer, A., Martini, L., Rigo, P., Pruner, S., Venuti, P. (2014). Predictors of mother-child quality and child attachment security in at-risk families. Frontiess in psychology 5(898):1-10..DOI: 10.3389/fpsyg.2014.00898

Gartstein, M.A., Iverson, S. (2014). Attachment security: the role of infant, maternal \& contextual factors. International Journal of Psychology \& Psychological Therapy 14 (2): 261-276

Grossmann, K., Grossmann, K.E. (2009). The impact of attachment to mother and father and sensitive support of exploration at an early age on childrens psychosocial development through young adulthood. Encyclopedia on Early childhood development 1-6

Hanum, N.L., Khomsan, A. (2012). Pola asuh makan, perkembangan bahasa, dan kognitif anak balita stunted dan normal di Kelurahan Sumur Batu, Bantar Gebang Bekasi. Jurnal Gizi dan Pangan 7(2): 81-88

Hastuti, D., Alfiasari, Chandriyani. (2010). Nilai anak, stimulasi psikososial dan perkembangan kognitif anak usia 2-5 tahun pada keluarga rawan pangan di Kab. Banjarnegara, Jawa Tengah. Jur. Ilm. Kel. \& Kons. 3 (1) 27-34

Hastuti, D. (2015). Pengasuhan: Teori dan Perinsip serta Aplikasinya di Indonesia. Bogor (ID) : IPB Press.

Ijzendoorn, Mv. (2007). Attachment at an early age (0-5) and it's impact on children's development. Encyclopedia on Early Childhood development 2: 1-4

Koonce, M.W.R, Gariépy, J.L, Propper, C.B., Sutton, K., Calkins, S., Moore, G., Cox, M.J. (2007). Infant and parent factors associated with early maternal sensitivity: A caregiver-attachment systems approach. Infant Behavior and Development. 30 114-126.

, Willoughby, M.T., Zvara, B., Barnett, M., Gustafsson, H., Cox, M.J. (2015). Mothers' and fathers' sensitivity and children's cognitive development in 
low-income, rural families. Journal of Applied Developmental Psychology 38 (2015) : 1-10. DOI: 10.1016/j.appdev.2015.01.001

Kranenburg, B.M.J, Ijzendoorn, M.Hv, Juffer, F. (2003). Less is more: meta-analyses of sensitivity and attachment interventions in early childhood. Psychological Bulletin 129(2): 195-215. DOI: 10.1037/0033-2909.129.2.195

[Kemendikbud] Kementrian Pendidikan dan Kebudayaan. (2015). APK/APM ECEP, SD, SMA Tahun 2014/2015 [internet]. [diunduh 2016 Juli 31]

Kunster, A.K., Fegert, J.M., Ziegenhain, U. (2010). Assessing parent-child interaction in the preschool years: a pilot study on psychometric properties of the toddler CARE-index. Clinical Child Psychology and Psychiatry. 15 (3): 379-389. DOI: $10.1177 / 1359104510367585$

LaMont, M. (2010). Mother-child attachment and preschool behavior problems in children with developmental delays. [disertasi]. Utah (US): Utah State University.

Loeb, S., Bridges, M., Bassok, D., Fuller, B., Rumberger, R.W. (2007). How much is too much? the influence of preschool centers on children's social and cognitive development. Economics of Education Review 26 (2007) 52-66. DOI:10.1016/j.econedurev.2005.11.005

Malmberg, L.E, Mwaura, P., Sylva, K. (2010). Effects of a preschool intervention on cognitive development among East-African preschool children: a flexibly timecoded growth model. Early Childhood Research Quarterly 26 (2011) 124-133. DOI:10.1016/j.ecresq.2010.04.003

Marlina, P.W.N. (2012). Studi keterkaitan antara status gizi dan pola asuh lingkungan dengan perkembangan kognitif anak usia prasekolah pada keluarga miskin Kecamatan Jalancagak Kabupaten Subang. [tesis]. Bogor (ID): Institut Pertanian Bogor

Megawangi, R. (2014). Kelekatan Ibu-Anak Kunci Membangun Bangsa. Bogor (ID): Indonesia Heritage Foundation

O'Connor, E., McCartney, K. (2007). Attachment and cognitive skills: an investigation of mediating mechanisms. Journal of Applied Developmental Psychology 28 (2007) 458-476. DOI:10.1016/j.appdev.2007.06.007

Pierrehumbert, B., Ramstein, T., Karmaniola, A., Halfon, O. (1996). Child care in the preschool years: Attachment, behaviour problems and cognitive development. European Journal of Psychology of Education.11 (2): 201-214

Ponciano, L. (2010). Attachment in foster care: the role of maternal sensitivity, adoption, and foster mother experience. Child AdolescSoc Work J (2010) 27:97114. DOI: $10.1007 / \mathrm{s} 10560-010-0192-\mathrm{y}$

Rispoli, K.M., McGoey, K.E., Koziol, N.A., Schreiber, J.B. (2013). The relation of parenting, child temperament, and attachment security in early childhood to social competence at school entry. Journal of School Psychology 51 (2013) 643-658. DOI: $10.1016 /$ j.jsp.2013.05.007

Santrock, J.W. (2007a). Perkembangan Anak.Rachmawati M, Kuswanti A, penerjemah; Hardani W, editor.Edisi ke-11 Jilid-1. Jakarta (ID): Erlangga.

. (2007b). Perkembangan Anak.Rachmawati M, Kuswanti A, penerjemah; Hardani W, editor.Edisi ke-11 Jilid-2. Jakarta (ID): Erlangga.

Saputri, L.E. (2010). Pengaruh gaya pengasuhan orang tua dan kecerdasaran emosional terhadap perilaku bullying remaja sekolah menengah pertama [skripsi]. Bogor (ID): Institut Pertanian Bogor 
Setyaningrum, S.R., Triyanti, Indrawani, Y.M. (2014). Pembelajaran di pendidikan anak usia dini dengan perkembangan kognitif pada anak. Jurnal Kesehatan Masyarakat Nasional 8 (6)

Solihin, R.D.M., Anwar, F., Sukandar, D. (2013). Kaitan antara status gizi, perkembangan kognitif, dan perkembangan motorik pada anak usia prasekolah. Penelitian Gizi dan Makanan 36 (1): 62-72

Spieker, S.J., Nelson, D.C., Petras, A., Jolley, S.N., Barnard, KE. (2003). Joint influence of childcare and infant attachment security for cognitive and language outcomes of low-income toddlers. Infant Behavior \& Development 26 (2003) 326-344. DOI:10.1016/S0163-6383(03)00034-1

Sukardi, A.N. (2011). Kajian riwayat perkembangan anak, sensitivitas dan kelekatan ibu terhadap anak usia 3-5 tahun di Kampung Adat Urug, Kabupaten Bogor [skripsi]. Bogor (ID): Institut Pertanian Bogor

Warsito, O., Khomsan, A., Hernawati, N., Anwar, F. (2012). Relationship between nutritional status, psychosocial stimulation, and cognitive development in preschool children in Indonesia.Nutr Res Pract 6 (5): 451-457. DOI: 10.4162/nrp.2012.6.5.451

West, K.K., Mathews, B.L., Kerns, K.A. (2012). Mother-child attachment and cognitive performance in examination of mediating mechanism.Early Childhood Research Quarterly 28 (2013) 259-270. DOI: 10.1016/j.ecresq.2012.07.00 